\title{
GROUNDWATER DROUGHT EVOLUTION IN NORTH-EASTERN PART OF ROMANIA
}

DOI: http://dx.doi.org/10.18509/GBP.2020.06

UDC: 556.313:551.577.38(498)

\author{
Minea Ionut ${ }^{1}$ \\ Boicu Daniel ${ }^{1}$ \\ Iosub Marina ${ }^{2}$ \\ Chelariu Oana-Elena ${ }^{1}$ \\ Enea Andrei ${ }^{2}$ \\ ${ }^{1}$ Alexandru Ioan Cuza" University of Iasi, Faculty of Geography and Geology, Romania \\ ${ }^{2}$ Integrated Center of Environmental Science Studies in the North Eastern Region, CERNESIM, \\ "Alexandru Ioan Cuza" University of Iasi, Romania
}

\begin{abstract}
Lack of rainfall in short time scales mainly affects soil moisture, whereas long-term rainfall deficit often affects streamflow and groundwater. Hydrogeological drought can be evaluate using specific index like Standardized Groundwater Index (SGI) on similar methodology used for Standardized Precipitation Index (SPI). The evaluation of hydrogeological drought was made for 15 hydrogeological wells developed on northeastern part of Romania in the period 1983 to 2018. The results show that there is a common evolution and good correlation (for more than $80 \%$ of pairs of meteorological stations and hydrogeological wells analyzed) between atmospheric drought and groundwater drought for cumulated periods of 6 and 12 months. In the same time the evolution of atmospheric and groundwater drought can be predictable using innovative analyzing method (ITA). For both phenomena just for SPI and SGI for cumulated periods of 6 months a slight tendency of increasing was observed.
\end{abstract}

Keywords: groundwater, drought index, evolution, North-eastern Romania

\section{INTRODUCTION}

Groundwater drought is a complex phenomenon that is manifested under specific water deficit conditions. The lack of precipitation, on the time scale, has an effect in reducing soil moisture and the water supply to the hydrographic network and groundwater. The result consists in decreasing the levels and river flows and increasing the depth of the groundwater level [1]. On the background of global climate changes consequences, the question of identification of the contribution of rainfall fluctuations on water resources from underground is posed. This aspect has been intensively analyzed in the last decade by identifying indices that highlight the transition mechanism between atmospheric and hydrological droughts like standardized precipitation index (SPI) and streamflow drought index [2]. The identification of a standardized index of hydrogeological droughts was natural, so [3] propose Standardized Groundwater Index (SGI) applied to groundwater level variations. This index has been re-analyzed and applied in a series of research aimed at analyzing hydrogeological droughts in different climatic conditions [4] or globally [5] or in the medium and long term [6]. For central and eastern Europe, the assessment of hydrogeological droughts was carried out in close correlation with the indices for evaluating atmospheric droughts $[7,8]$ or with the hydrogeological structures in which 
the groundwater is found [9]. At the same time, the tendency of evolution of this phenomenon was sought to be identified using innovative trend analysis method (ITA) proposed by [10] for all indicators associated with hydrological and hydrogeological droughts [11].

In Romania, the effects of hydrogeological droughts on the variation of the groundwater level were partially analyzed based on the evolution of the climatic parameters on the flow of rivers $[12,13]$ and the recharge capacity of the groundwater [14]. In this sense, in this paper we propose two major objectives: i) applying a standardized index to highlight hydrogeological droughts (SGI) and ii) identifying the tendency of hydrogeological droughts using ITA.

\section{DATASETS AND METHODOLOGY}

\section{Datasets}

Given the analyzed area extending over an area of more than $8000 \mathrm{~km}^{2}$, in the northeastern part of Romania, we opted to highlight hydrogeological droughts by analyzing groundwater levels (monthly and annual) from 10 hydrogeological drills for a period for 36 years (from 1983 to 2018). This area is characterized by frequent phenomena of atmospheric and hydrological drought [15]. At the same time to see the evolution of the hydrogeological droughts in correlation with the atmospheric ones, climatic data were used regarding the monthly and annual precipitations from 2 weather stations (Botosani and Iași) for the same time period. (Figure 1).

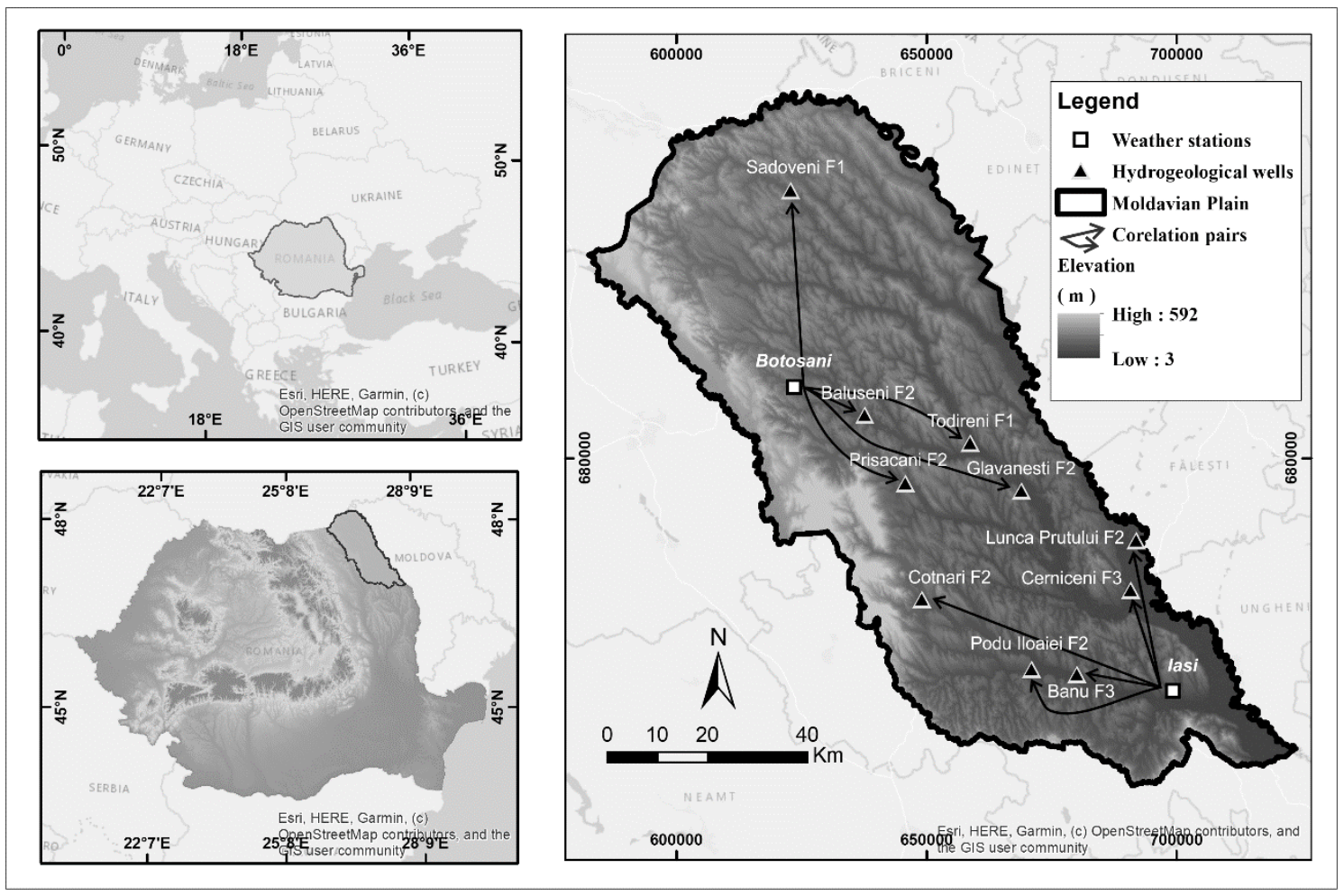

Figure 1. Weather stations and hydrogeological wells analyzed from study area

\section{Methodology}

The methodology for identifying meteorological droughts was initiated by [16] and applied in numerous scientific studies. Including the World Meteorological Organization 
[17] indicates the use of this methodology in identifying atmospheric droughts at regional and global level. To identify the periods of atmospheric drought in the eastern part of Romania, the associated SPI methodology and described in the DrinC program was used [18].

The analysis of the hydrogeological droughts was performed based on the methodology proposed by [3]. Because the values describing the groundwater level have not a statistical distribution (log-normal or Gamma) it is necessary to use a non-parametric normal scores transform distribution [6]. After this transformation of the data the SGI values can be obtained using the formula [4]:

$$
\mathrm{SGI}_{\mathrm{q}}=\frac{G_{i}-\overline{G_{i}}}{\sigma_{G}}
$$

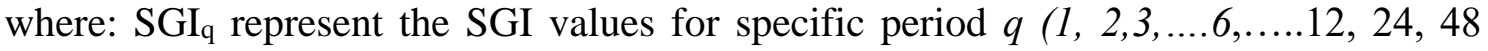
months) $G i$ and $\bar{G}_{l}$ is the monthly average groundwater level and the mean, respectively and $\sigma_{G}$ is the standard deviation. The results were classified as follows: for SGI values under -2 correspond to extreme drought, - the SGI values between -2 and $-1,5$ correspond to severe drought, the SGI values between $-1,5$ and -1 correspond to moderate drought, values of SGI between -1 and 0 correspond to minor drought and SGI values over 0 show that no drought produced.

To analyze the evolution of groundwater drought ITA method was used. This method involves two steps. In first step the entire dataset is divided into two equal and orderly series [19]. In the present study two sub-series of data, each of 18 years each, were extracted (1983-2000 and 2001-2018). In the second step the two sub-series are represented in a two-dimensional coordinate system as scatter points and compared to the 1: $1\left(45^{\circ}\right)$ line. If in this representation some of the points are above the median line, they show an increasing trend, and if they are below the median line they represent a decreasing trend. If they are along the median line no trend of the points can be found. The values obtained for SPI and SGI calculated for different period were represented according to this method.

\section{RESULTS}

The multiannual regime of atmospheric precipitation and groundwater level variations does not allow the identification of graphical or statistical correlations between these parameters as can be seen in figure 2 .

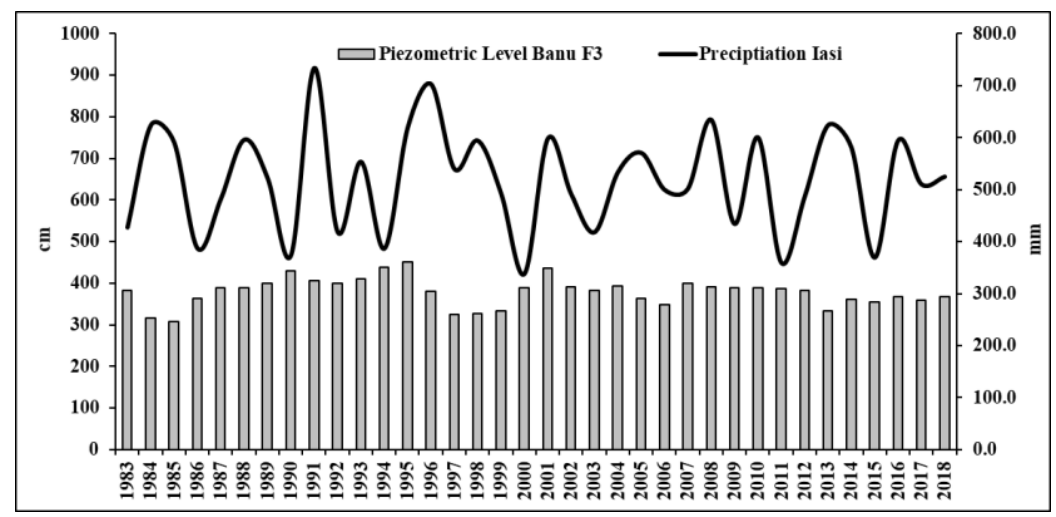

Figure 2 Variation of groundwater level (at Banu F3 hydrogeological well) and precipitation (at Iasi meteorological station) between 1983 and 2018 
The application of the associated SPI and SGI methodologies revealed a certain degree of correlation between the occurrence of atmospheric droughts and those of underground droughts. This can be better seen from the annual distribution of SPI and SGI values at 6 and 12 months respectively (Figure 3 and Figure 4).

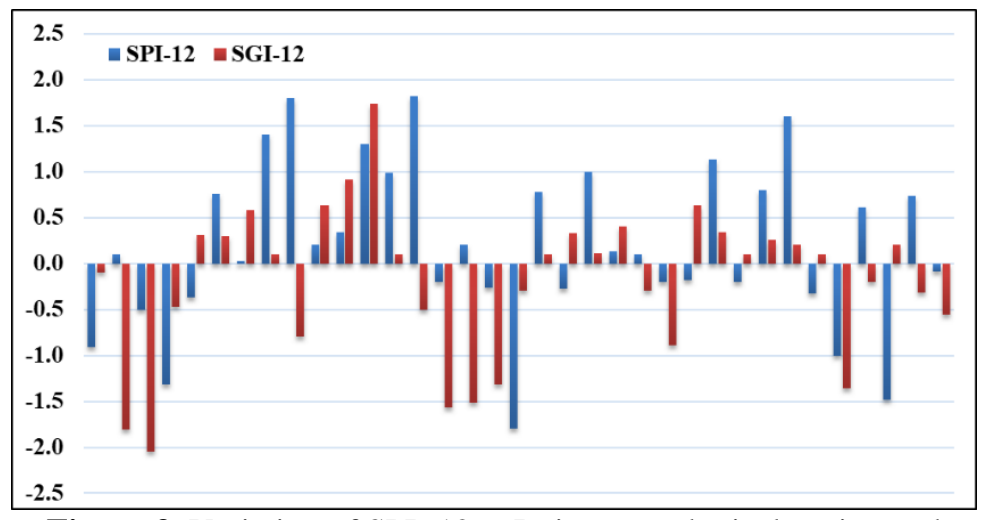

Figure 3. Variation of SPI -12 at Iasi meteorological station and Banu F3 hydrogeological well between 1983 and 2018.

In order to identify this degree of correlation, a correlation coefficient was calculated $r$ (Pearson correlation coefficient) between SPI and SGI values for pairs of meteorological stations and hydrogeological stations (Table 1). The highest values of the correlation coefficient $r$ with statistical significance are observed between the pairs SPI-6 and SGI-6 (for all pairs) and SPI-12 and SGI-12 for $83 \%$ of the analyzed pairs. Obviously, in certain situations as is the case of the Botosani/Baluseni F3 pair with one exception, there is a strong correlation between SPI and SGI for the whole period. This type of correlation has also been identified in other analyzes carried out $[4,6,11]$ and it is due to the accumulation in time of the effects of atmospheric droughts that break with a certain gap and in the variation of the groundwater level up to very long periods of time. type of 24 or even 48 months. An important role in the production of this gap is given by the local natural conditions in which the groundwater is confined conditions that can propagate or reduce the effects of atmospheric droughts [20]. At the same time, we must also take into account the evolution of the climatic and hydrological elements in close relation with the climatic changes observed in this region $[21,22]$

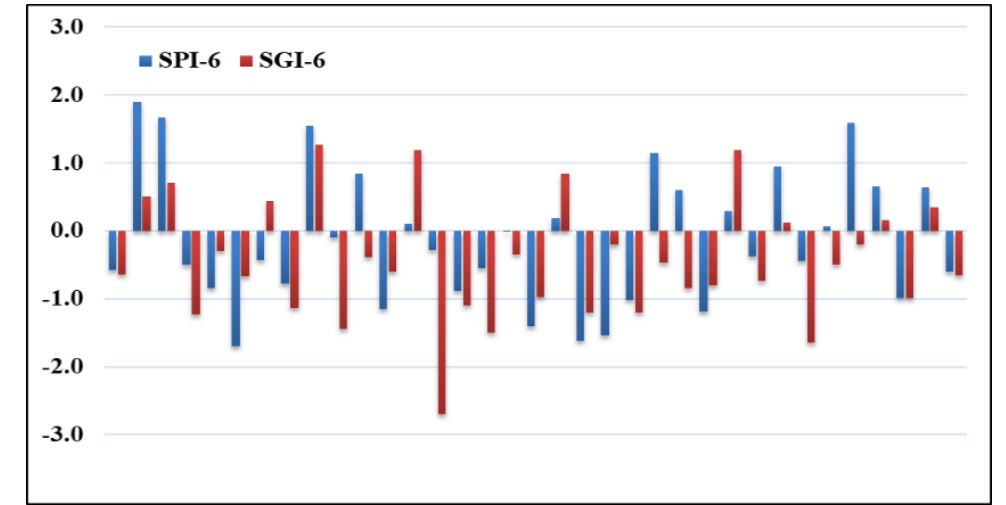

Figure 4. Variation of SPI 6 and SGI-6 at Botosani meteorological station and Baluseni F3 hydrogeological well between 1983 and 2018 
Table 1. Correlation matrix between different SPI and SGI values for pairs of meteorological stations and hydrogeological stations

\begin{tabular}{|l|c|c|c|c|c|c|c|c|c|c|c|c|c|c|}
\hline $\begin{array}{l}\text { Meteorological } \\
\text { station/ } \\
\text { Hydrogeologycal } \\
\text { well }\end{array}$ & $\mathbf{1}$ & $\mathbf{2}$ & $\mathbf{3}$ & $\mathbf{4}$ & $\mathbf{5}$ & $\mathbf{6}$ & $\mathbf{7}$ & $\mathbf{8}$ & $\mathbf{9}$ & $\mathbf{1 0}$ & $\mathbf{1 1}$ & $\mathbf{1 2}$ & $\mathbf{2 4}$ & $\mathbf{4 8}$ \\
\hline Iasi/Banu F3 & 0.25 & 0.14 & 0.32 & 0.27 & $0.41^{*}$ & $0.62^{*}$ & 0.35 & $0.41^{*}$ & $0.43^{*}$ & 0.39 & $0.41^{*}$ & $0.48^{*}$ & $0.47^{*}$ & 0.35 \\
\hline Iasi/Carniceni F3 & 0.18 & 0.22 & 0.32 & 0.22 & 0.25 & $0.44^{*}$ & 0.23 & 0.12 & 0.15 & 0.18 & 0.39 & 0.28 & 0.15 & 0.18 \\
\hline Iasi/Podu Iloaiei F2 & 0.26 & 0.28 & 0.35 & 0.45 & 0.44 & $0.55^{*}$ & 0.35 & $0.44^{*}$ & 0.42 & $0.48^{*}$ & 0.48 & $0.50^{*}$ & 0.36 & 0.28 \\
\hline Botosani/Baluseni F3 & $0.46^{*}$ & 0.42 & $0.48^{*}$ & $0.54^{*}$ & $0.61^{*}$ & $0.72^{*}$ & $0.72^{*}$ & $0.73^{*}$ & $0.62^{*}$ & $0.59^{*}$ & $0.60^{*}$ & $0.65^{*}$ & $0.48^{*}$ & $0.52^{*}$ \\
\hline Botosani/Sadoveni F1 & 0.42 & 041 & $0.49^{*}$ & $0.48^{*}$ & $0.51^{*}$ & $0.50^{*}$ & $0.55^{*}$ & $0.58^{*}$ & $0.56^{*}$ & $0.55^{*}$ & $0.48^{*}$ & $0.52^{*}$ & $0.51^{*}$ & $0.48^{*}$ \\
\hline Botosani/Prisacani F2 & 0.28 & 0.39 & $0.41^{*}$ & 0.44 & $0.48^{*}$ & $0.48^{*}$ & 0.42 & 0.36 & 0.35 & 0.39 & $0.44^{*}$ & $0.45^{*}$ & 0.42 & 0.43 \\
\hline
\end{tabular}

The methodology associated with ITA was applied to highlight the trends of the hydrological droughts for the values obtained for the couples of meteorological stations and hydrogeological wells where a statistically significant correlation coefficient was obtained, respectively SGI 6 and SGI 12. If, in the case of the SPI 12 and SGI 12 for all the station trends, the increasing or decreasing trends are not graphically observable (Figure 5), in the corresponding SPI 6 and SGI-6 there is a slight tendency to increase the atmospheric and hydrogeological droughts for the latter. years (Figure 6). Obviously, these trends cannot be the basis of a long-term forecast but they can be a starting point in analyzing the evolution of groundwater resources and associated management plans. On the other hand, these trends also take into account the local geological conditions responsible for propagating the water deficit to groundwater [23].

\section{CONCLUSIONS}

The analysis of hydrogeological droughts in a geographical area where the frequency of atmospheric droughts is quite high may require a series of practical measures to reduce the impact on human communities. The negative effects can be greatly diminished by knowing the trends of these phenomena, quite strongly influenced by the evolution of the atmospheric water deficit (see the quite well-established correlations between the atmospheric droughts and the hydrogeological droughts for cumulative periods of 6 and 12 months respectively). Local and regional water resource management plans [should take into account this type of analysis, especially as at present about 50 of the population of the analyzed area are aligned with groundwater and the consequences of global and regional climate changes are difficult to ascertain. Local and regional water resource management plans [should take into account this type of analysis especially since at present about $50 \%$ of the population of the analyzed area is supplied with groundwater and the consequences of global and regional climate changes are difficult to quantify.

\section{Aknowledgements}

This work was financially supported by the Department of Geography from the "Alexandru Ioan Cuza" University of Iasi, and the infrastructure was provided through the POSCCE-O 2.2.1, SMIS-CSNR 13984-901, No. 257/September 28, 2010 Project, CERNESIM.

\section{REFERENCES:}

[1] Tallaksen, L.M., van Lanen, H.A.J., Hydrological Drought Processes and Estimation Methods for Streamflow and Groundwater, Developments in Water Sciences 48, theNetherlands: Elsevier, 2004. 
[2] van Loon A.F. Hydrological drought explained, WIREs Water, 2:359-392, 2015.

[3] Bloomfield J.P., Marchant B.P. Analysis of groundwater drought building on the standardised precipitation index approach, Hydrol. Earth Syst. Sci.,17, 4769-4787, 2013.

[4] Yeh H.F., Chang C.F., Using Standardized Groundwater Index and Standardized Precipitation Index to Assess Drought Characteristics of the Kaoping River Basin, Taiwan, Water, Resources, 46, 5, 670-678, 2019.

[5] van Lanen H.A.J., Wanders N., Tallaksen L.M., Van Loon A.F., Hydrological drought across the world: impact of climate and physical catchment structure, Hydrol. Earth Syst. Sci., 2013, vol. 17, pp. 1715-1732, 2013.

[6] Bloomfield J.P., Marchant B.P. McKenzie A.A., Changes in groundwater drought associated with anthropogenic warming, Hydrol. Earth Syst. Sci., 23, 1393-1408, 2019.

[7] Li B., Rodell M..,Evaluation of a model-based groundwater drought indicator in the conterminous U.S. J. Hydrol., 2014.

[8] Kubicz J., Bak B. The Reaction of Groundwater to Several Months' Meteorological Drought in Poland, Pol. J. Environ. Stud. Vol. 28, 1, 187-195, 2019.

[9] Haas, J.C., Birk, S., Characterizing the spatiotemporal variability of groundwater levels of alluvial aquifers in different settings using drought indices. Hydrol. Earth Syst. Sci. 21, 24212448, 2017.

[10] Șen, Z., Innovative trend analysis methodology. J Hydrol Eng 17, 1042-1046, 2012.

[11] Haas, J.C., Birk, S., Trends in Austrian groundwater - Climate or human impact? Journal of Hydrology: Regional Studies 22, 2019.

[12] Minea I., Croitoru A.E., Climate Changes and their impact on the variation of groundwater level in the Moldavian Plateau (Eastern Romania), International Multidisciplinary Scientific Geoconferences, SGEM 2015, Conference Proceedings, Vol I, Hydrology and Water Resources, $137-145,2015$

[13] Minea I., Croitoru A.E., Groundwater response to changes in precipitation in north-eastern Romania, Environmental Engineering Management Journal, 16, 3, 643-651, 2017

[14] Boicu D., Minea I., Chelariu O.E., Iosub M., 2019. Evaluation on groundwater recharges capacity using AHP method. Case study: The Moldavian Plain, Aerul şi apa componente ale mediului, 181-188.

[15] Minea I., Sfîcă L., Assesment of hydrological drought in the north-eastern part of Romania. Case study - Bahlui catchment area, Aerul şi apa componente ale mediului, 93-100, 2017.

[16] McKee, T. B., Doesken, N. J., and Leist, J., The relationship ofdrought frequency and duration time scales, 8th Conference on Applied Climatology, 17-22 January 1993, Anaheim, California, 179-184, 1993.

[17] World Meteorological Organization (WMO), Standardized Precipitation Index User Guide, edited by: Svoboda, M., Hayes, M., and Wood, D., WMO-No. 1090, WMO Geneva, Switzerland, 2012.

[18] Tigkas D., Vangelis H., Tsakiris G., DrinC: a software for drought analysis based on drought indices. Earth Science Informatics, 8 (3), 697-709, 2015

[19] Dabanli I., Șen Z., Yelegen M.O., Șișman E., Selek B., Guclu Y.S., Trend assesment by the innovative Șen Method. Water Resour Manag, 30: 5193-5203, 2016.

[20] Minea I., Butelcă D., Niacşu L., Modele de variaţie a nivelului freatic în condiţii de secetă. Studiu de caz bazinul superior al Bârladului, Geographia Napocensis, IV, 1, 75-82 (in Romanian), 2012.

[21] Croitoru AE, Minea I., The impact of climate changes on rivers discharge in Eastern Romania. Theor Applied Climatol, 1434-4483, 2015.

[22] Croitoru, A.E., Piticar A, Sfica L, Harpa GV. Rosca C.F., Tudose T, Horvath C, Minea I., Ciupertea F.A., Scripca A.S., Extreme Temperature and precipitation Events in Romania, Romanian Academy Press, Bucharest, 2018.

[23] Minea I., Crăciun I., Simulation models to evaluate the groundwater resources in Bahlui river basin, Romania. Journal of Environmental Protection and Ecology, 1600-1607, 2012. 